\title{
社会変容を背景とした建築家の新職能に関する基礎的考察 \\ 米国の事例を題材として \\ A STUDY ON THE NEW PROFESSION OF ARCHITECT THROUGH THE CURRENT SOCIAL TRANSFORMATION
}

Based on the examples in the U.S.

岡本圭介*1, 野城智也 ${ }^{* 2}$

\section{Keisuke OKAMOTO and Tomonari YASHIRO}

\begin{abstract}
In this study, we conducted an interview survey at the offices that conduct an Architect-Led- Design-Build business in New York City, and at a developer company catering to in-house design and construction, as well as continued investment-type crowdfunding in Portland City. We analyzed the case studies of operators involved in the scheme design of a typical regional economic zone, and we conducted an interview survey with platform operators recently seen in Japan. We then clarified the superiority and issues of each model, categorized them, and proposed the social significance of the architect as subjects who comprehensively remodels the combination.
\end{abstract}

Keywords : Architect, Profession, ALDB, Design, Developer, Funding 建築家, 職能, ALDB, 設計, 開発, 資金調達

\section{1. はじめに}

\section{1-1. 研究背景と目的}

昨今、人口増加を前提とした経済資本主義原理に基づく産業構造 に対して諸分野から上がり始めている疑問の声を背景に、パブリッ ク領域において金融包摂的な構造変化注 1) が起こっていると言われ ている。また、プロジェクト領域における建築家の職能領域も、情 報技術の進展や市場構造の漸進的な変化などを背景に変容注2) が起 こっていると考えられる。建築生産行為による社会奉仕活動が建築 家の役割であるとらえた場合、統括的な視点に基づき双方の領域を またぎながら、社会と建築の関係性を調節する職能の社会的意義は、 今後高まっていくと考えられる。

例えば、未だ日本語における「建築家」の定義は曖昧な側面を多 く残している一方で、分業体制が伝統的に明文化されている米国に おいては、既存の「アーキテクト」の定義に規定されている設計業 務活動にとどまらない分野領域で活動を行う事例が、近年注目を浴 びるようになってきている。そこで本研究では、法制度や経済市場 において現在起きている変化に相互応答しながら、これまでと異な る職能領域を扱い実際に空間生産を実装している米国の建築事務所 に着目した。建築空間プロセスに関与する一般的なステークホルダ 一の関係性をデリバリーモデル注3) で表した場合、Figure. 1 のよう に、パブリック領域(Public Sphere) とプロジェクト領域(Project Sphere)の二側面に分割してとらえることができる。本論文は、文
献調查、インタビュー、事例調査を通した実態把握に基づき、デリ バリーモデルを用いて、社会変容の現段階における建築家職能の暫 定的な様態をとらえ、今後の建築家の社会的意義を統括的な視点で 考察することを目的とする。

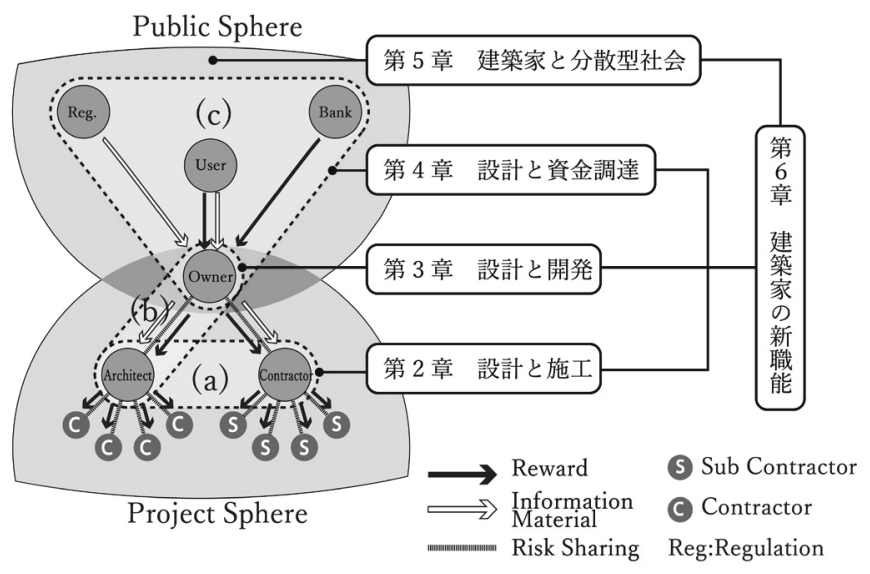

Fig. 1 The Organization of this thesis with delivery model

\section{1-2. 本論文の構成}

本論文では、まず建築マネジメント論注 4)・情報技術史注5)・建築 士職能論注 6) に関する既往研究を通して、従来の建築家の職能に関 わる論考を整理する。次に、各々の関係性が変化しつつあることを
*1 東京大学大学院工学系研究科建築学専攻 修士課程

*2 東京大学生产技術研究所 教授.工博
Master Course, Dept. of Architecture, Faculty of Eng., The University of Tokyo

Prof., Institute of Industrial Science, The University of Tokyo, Dr.Eng. 
踏まえて、米国 New York 市を拠点に活動する事業者への直接イン タビュー調查(事例数が多くないために質的調查をべースとした調 查)を行い、設計者と施工者、設計者と発注者の領域境界(図 $1 \mathrm{a}, \mathrm{b}$ ) で起きている動向の実態把握を試みる。その試みを踏まえ、現代の 資金調達プロセス(図 $1 \mathrm{c}$ )の変化動向を整理し、それを活用した米国 Portland 市における建築プロジェクトの事例分析を行う。

そして、資金調達において近年米国を中心に見られ始めた $\mathrm{P} 2 \mathrm{P}$ 注

7) 型エクイティ投資クラウドファンディングプラットフォームの事 業主体に着目し、日本で最初に不動産市場におけるエクイティクラ ウドファンディング事業を開始した鬼頭氏へのインタビュー調査を 通して、分散社会における動的な平衡状態を維持するエコシステム の設計主体としての新職能の可能性について考察した。これらの分 析考察から得られた知見をもとに、建築家の新職能の類型化を試み、 本論文の結語とする。

\section{2. 設計と施エの境界領域における動向}

\section{2-1. デザインビルドに関する日米両国概況論}

米国の建築調達方式には DBB（Design-Bid-Build：設計施工分 離) 方式、CM (Construction Management：コンストラクション・ マネジメント) 方式、DB (Design-Build：デザインビルド) 方式な どがある。DBIA によれば注8)、1985 年に公共・民間の非住宅建築 プロジェクトの $10 \%$ を占めるに過ぎなかった DB方式の市場占有率 は 2018 年段階で $44 \%$ (CM 式が $35 \%$ 、DBB 式が $19 \%$ ) と市場最大 の占有率に至る状況となっている。米国における DB は通例、請負 業者主導 (Contractor-Led-Design-Build) を指し、発注者の設計関 与割合が増えるとともに、その分のリスクを施工業者が負担する形 をとるためアーキテクトの権限が縮小されることが懸念されてきた。 日本では DBB 方式に関する標準約款しか存在しないにも関わらず ゼネコン (GC) 主導型の設計施工一貫方式が大規模プロジェクト で採用されることが多くあった。この要因として安藤注9) は、経 済成長期を通じて GC が本来発注者側に内在したリスクを多めに引 き取り追加投資を自ら行ってリスク相殺を図りつつ、契約後の追加 利益を獲得することに努めてきた背景に起因すると分析している。

\section{2-2. Architect-Led-Design-Build (ALDB)}

Mortimer 注1 0) は、1990 年代頃から見られるようになった米国 のデザインビルドに関する研究の中で、主流である施工者主導と区 別するために建築家主導の Architect-Led-Design-Build (ALDB) と いう言葉が出現したと指摘している。ALDB は民間市場を中心に実 践がなされており、デザインビルドの普及によるアーキテクトの権 限縮小に対するオルタナティブな役割モデルの可能性の一つとして 近年米国で注目を集めている。

Quatman 注1 1) は、ALDB を実行するには、設計事務所が施工 管理能力を獲得する技術的能力と、リスクを負うための資本的能力 が求められることが多いとされていると述べている。これらの能力 を具備することが障害になり、米国においても事例は少ない。

\section{2-3. インタビューによる実例調査}

New York 市を拠点にALDB プロジェクトを実践している GLUCK+と Leroy Street Studio (LSS) の二社にインタビューし、 各々以下の資料を得た。

(1) GLUCK+ (Interviewee; Tom Gluck)
ALDB の有用性と課題、デザインとの関係性について具体的なプ ロジェクトベースの情報と、社内共有用のドキュメントとして Matrix of Responsibility、CD-DD フェイズ(基本-実施設計段階)か らディテールの素材とコストとデザイン性の検討を記した詳細図面。

(2) Leroy Street Studio (Interviewee : Greg Heasley)

ALDB の特にフローに関する有用性と課題、デザインとの関係性 について具体的なプロジェクトベースの情報と、ワークフロー模式 図、CPM 方式スケジュールデータ注 121

Figure 2 は、GLUCK +の Tom Gluck 氏へのインタビューで得ら れた図面の一部を抜粋したものである。Tom は、水切りの断面形状 をデザインの観点から決定し、素材・長さから社内で見積を行い、 通例の $\mathrm{CM}$ 会社が行う查定よりも安く、なおかつデザイン性の高い 提案を行うことに成功していると述べている。
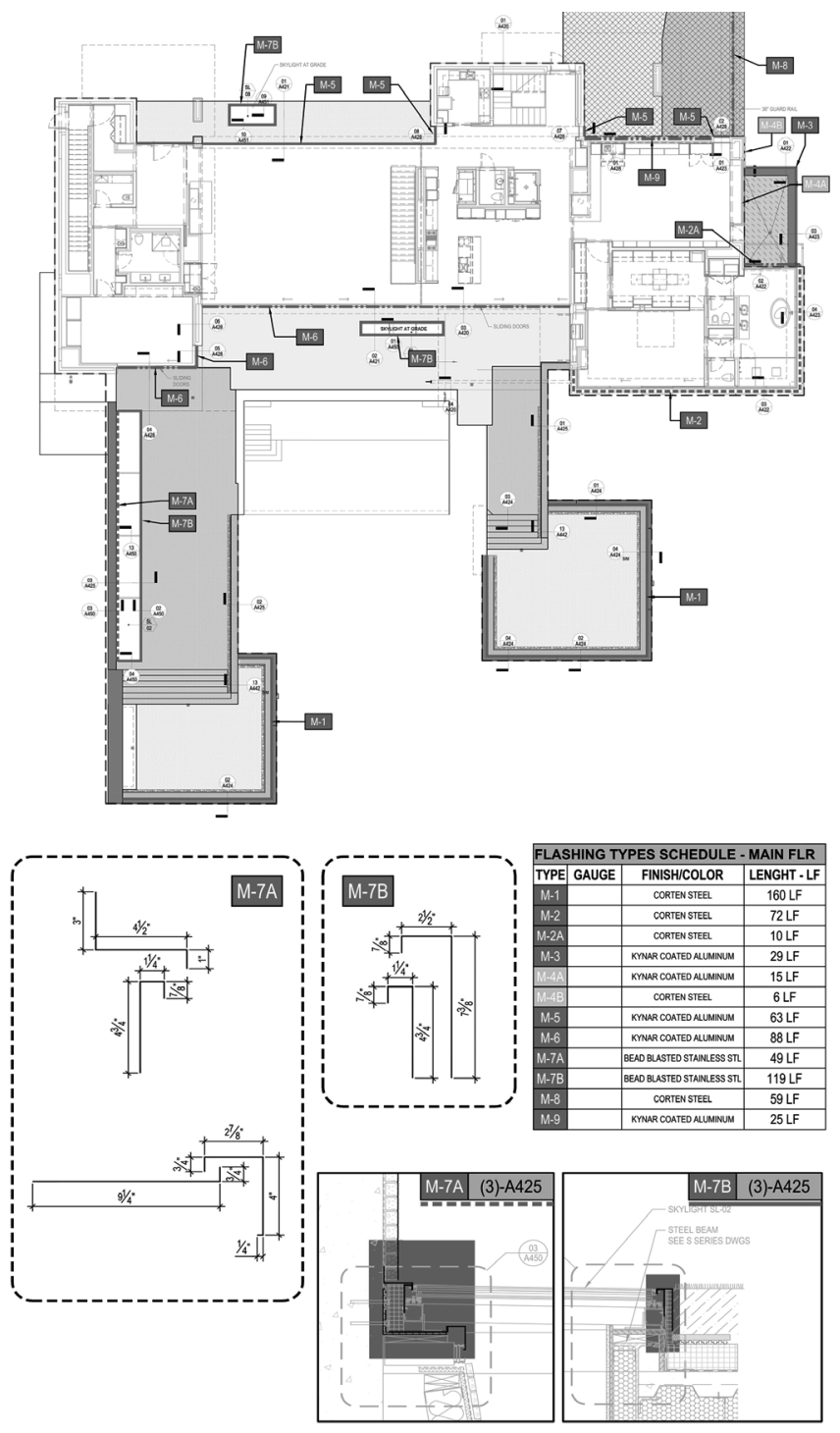

Fig. 2 A drawing showing how Gluck+ can cost effectively buy parts of the project (GLUCK+)

\section{2-4. 調査結果}

2 社の実例調查から得られた証言を、以下の通りALDB の利点と 課題について要約する。 


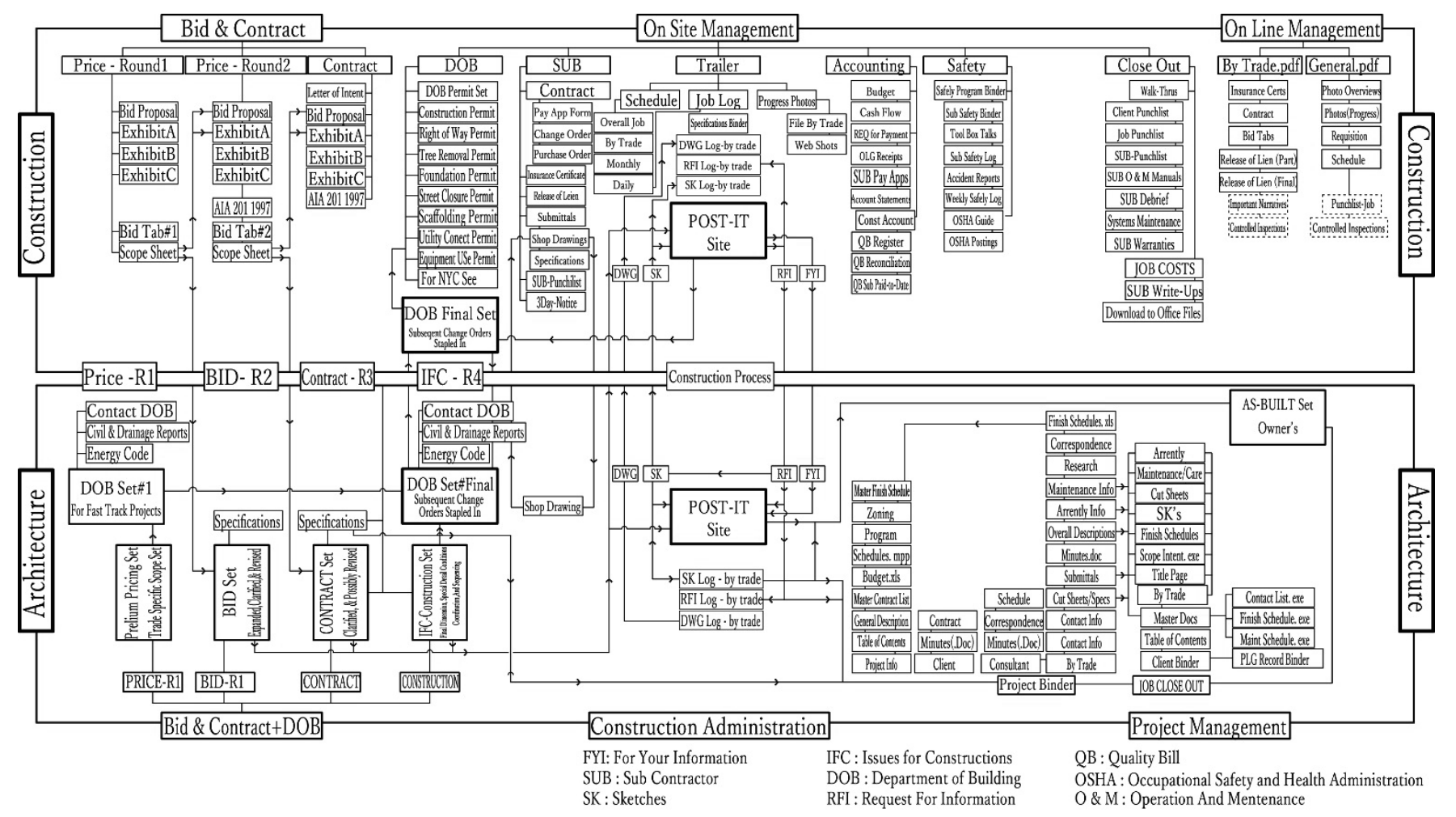

Fig.3 Data flow of ALDB process (GLUCK+)

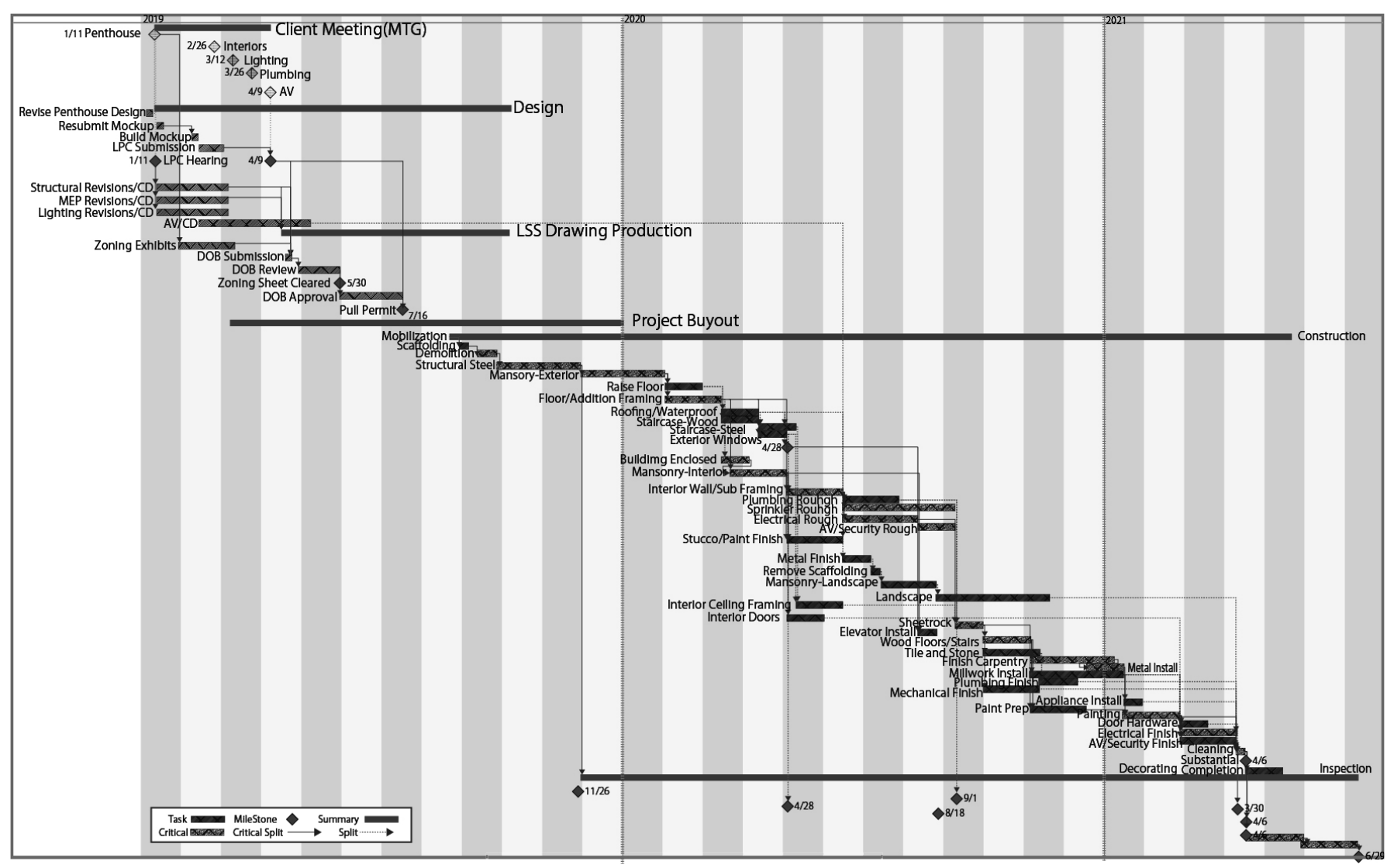

Fig. 4 CPM of a project (LSS)

（優位点 1）設計変更のトータルプロセスにおける柔軟性と透明性： 詳細設計と予算をパッケージごと確定できるため、施工期間中に も細かな設計変更とそれに伴う見積を検討できる。
（優位点 2）経費の透明性：

工期中の設計変更に伴う予算の変動があるためクライアントはい つでも予算の使われ方を確認することが可能となる。 
（優位点 3）従来方式の責任分界点による情報ギャップの補填: 施工業者の理解能力に依存するデザイン具現化に関する施工プ ロセス上における不確定要因が排除される。

（優位点 4）対処領域の汎用性によるコストと工期の低減:

予見性の低い課題に対する対処をスムーズに行うことができる。 （優位点 5) 受注者側の利益率の増加：

受注側は設計料と施工管理料を得るので全体の利益率が増加する。 （優位点 6）プロセス初期からの製造業者とのデザイン検討：

コンサルタントの対応能力外にある現場製作上でのデザインエッ センスをプロセス初期段階から検討可能となる。

（課題 1）公共事業市場上での制限：

公共工事の DB 方式は請負業者主導型の競争入札が一般的である ため、ALDB ないしアーキテクト主導の JV 型のモデルの導入制限 があると Greg は述べている。

（課題 2) 発注者との利益相反関係構造:

発注者との合意形成プロセスの難易度と重要度が増す。

（課題 3）組織形態の制限と保険コスト:

同一人物が複数の職能領域を実行する場合も別事業体として契約 する必要があり、それぞれに別の種類の保険・弁護士コストなどが かかる。

（課題 4) 人材取得と社内育成の難易度:

設計能力と施工管理能力を育成する体系が少ないため人材獲得や 組織運営の難易度は、従来と比較して高くなる。

Figure.3 は、インタビュー調查で得られた ALDBによる $\mathrm{CA}($ Construction Administration)フェイズ以降の設計施工プロセ スの情報データフローを示している。従来二分化されている建築と 施工を同一主体が行うことで、上下間の情報フローを効率的に進め ることを説明している。特に工作図に関してはALDBならではの対 応の速さが発揮されるとTom は述心゙ている。

Figure. 4 は Leroy Street Studio 提供の CPM データを編集した 図である。デザイン段階から施工計画を加味したスケジュールを組 んでいることが示されている。

\section{2-5. 調査分析小結：発注者との合意形成の重要性}

以上の調查により、ALDB はデザインフェイズから施工性を加味 したデザインとコスト管理を容易にすることや、施工期間において も情報フローの効率化を可能にすることといった利点があることが 明らかになった。一方で、複雑化する専門領域の管理上のハードル の高さや、発注者サイドから見た信頼性の構築などの課題も見受け られた。まだ一般的でないことに起因する信頼性の低さを改善する ための実績構築や、公共市場における法制度上の制約条件の緩和を 目指す動きなどが直近の課題解決として期待される。

\section{3. 設計と開発の境界領域における動向}

\section{3-1. Architect-Led-Developer}

米国ではJohn Portman をはじめとして不動産業に関与する形の アーキテクトは昔から存在した。しかし、近年の金融不動産業界の 体制変化を受けて建築設計業務と不動産開発に関わる業務を両方兼 ねる新たなロールモデルの価值が議論されるようになってきた。現 状においては、"Architect \& Developer"や"Non-Client Architect" などの言葉が散発的に使われているが、名称や語義は定まっていな
い。本論文では便宜的に、米国におけるアーキテクトとディベロッ パーの責任能力（もしくはその一部）の双方を有する個人主体、あ るいはそのような個人を意思決定者として含む事業体によるデザイ ン主導の開発行為を、Architect-Led-Developer (ALD) と呼称する こととし、考察を進めた。

\section{3-2. 米国アーキテクト主導型不動産開発手法に関する考察}

James Petty 注 13 ) は近年活発化している ALD 事業を行うアーキ テクトへのインタビュー活動や大学機関におけるカンファレンス主 催活動を「Architect \& Developer (2018)」にまとめ、方法論の体 系化を試みている。James の論考を参照したうえで、さらに補足と して本人に口頭インタビューを行い、米国における ALD の実践と 課題の抽出と整理を試みた。

Table.1 は、James がまとめている、米国における ALDによる住 宅不動産開発事例における自己資金補填のためのクリエイティブフ アイナンスツールの一例をした表である。社会的公益性の認められ るプロジェクトに対する補助金や税額控除、保険や様々なローン制 度が組み合わされている。資金調達の組み合わせや取捨選択なども、 建築デザインにおけるツールの一種とみなす認識が、米国では幅広 く共有されつつある動きがあると James は述べている。

Table1 Examples of creative finance tools in the US 参考文献 2)

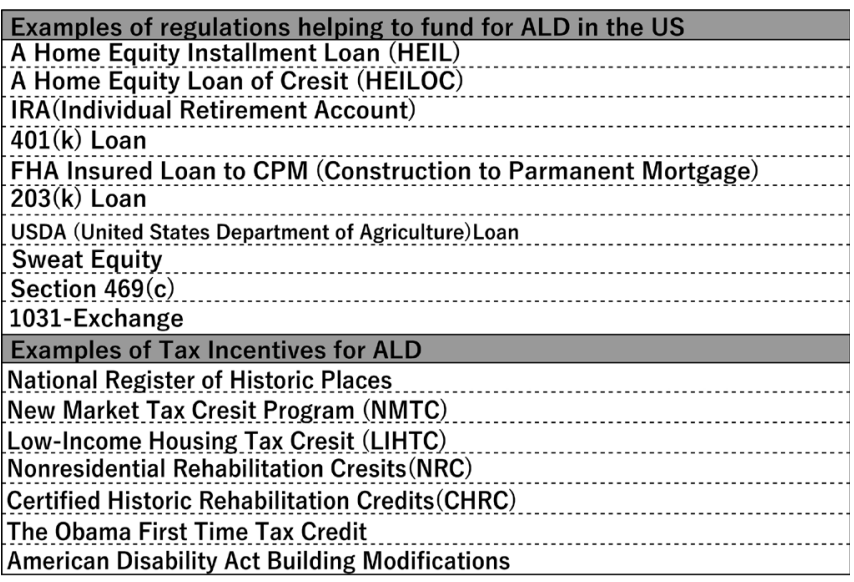

\section{3-3. ALD 実践主体へのインタビュ一調査}

New York 市を拠点にALD 活動とALDB 活動の両方を同時に展 開している Alloy Developmentにリモートインタビューを行い、以 下の資料を得た。

職員構成やプロジェクト構成・フィー構成などの情報と MoR (Matrix of Responsibility)

Table.2 はその責任含有項目箇所数を求めたものであり、す心゙ てのフェイズにおいて Alloy の責任が大きいことがわかる。 ステークホルダー関係を示した Entity of Matrix (Figure.5)。 開発プロジェクトのうち人物 $\mathrm{A}(\mathrm{Jared})$ がディベロッパー、設計 者、施工管理者として関与していることを示している。 同一人物が 3 役職で署名した発注変更届の一例（Figure.6）。 施工中の発注変更書類の一部だが、発注者、設計者、施工管理 者すべて同一人物(Jared)による署名であることがわかる。

Jared(CEO, Alloy Development)は、ALD 事業のメリットとして、 金融機関側からは空口が少ないため好まれやすいと述心゙ている一方 で、信頼性を今後蓄積していくことが重要だと述べている。 
Table 2 Examples of creative finance tools in the US

$\begin{aligned} & \text { Architect of Record A A } \\
& \text { Interior Design Firm B B } \\
& \text { Exterior Design Firm C C }\end{aligned}$
\begin{tabular}{|l|c|c|c|c|}
\hline Phase/Task & \multicolumn{5}{c|}{ Tower } \\
\hline & A & Alloy & B & C \\
\hline General: & 1 & 10 & 1 & 1 \\
\hline Programming \& Concept Design & 0 & 10 & 0 & 0 \\
\hline Schematic Design & 0 & 23 & 1 & 0 \\
\hline Design Development & 0 & 26 & 9 & 16 \\
\hline Construction Document / Bidding & 0 & 32 & 12 & 10 \\
\hline Construction Administration & 0 & 20 & 10 & 9 \\
\hline Toal & 1 & 111 & 33 & 36 \\
\hline
\end{tabular}

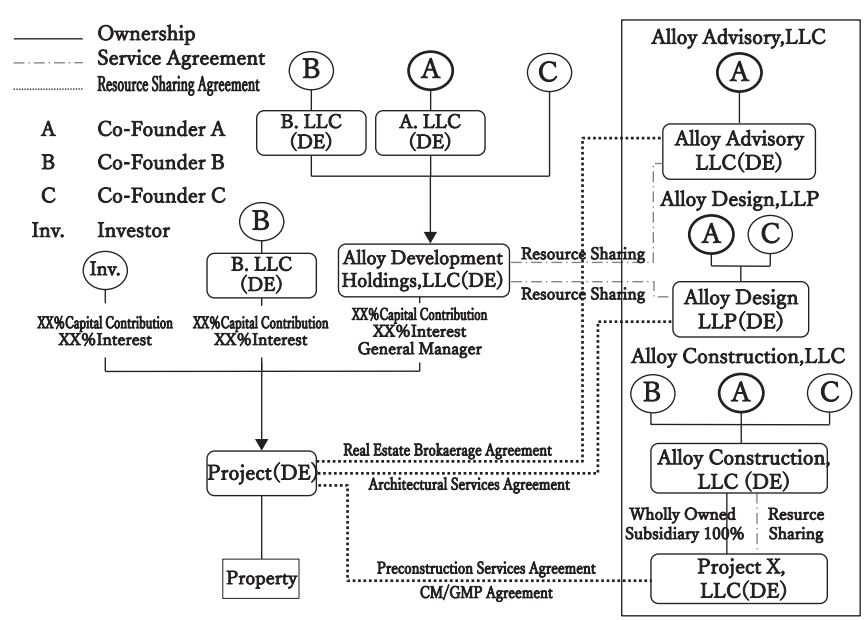

Fig. 5 Entity Matrix of AIOP model (Alloy)

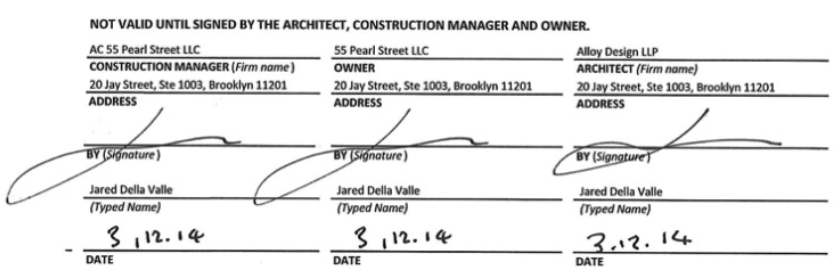

Fig. 6 part of transaction document showing every signature is written by single person (Alloy)

本論文では、このように $\mathrm{ALD}$ 活動を行いつつ ALDB も行う一主 体をAIOP(All in One Package) と呼称することとする。Figure5 は AIOP の責任能力を説明している。

\section{3-4. インタビュー調査で得られた証言}

Alloy Development の Jared の証言から得られた ALD の特徵を 以下にまとめる。

(1)インテグラル型の組織内部構造 :

組織外との責任分界点は Table.2 より明確であることがわかるが Jared は「社内分業ではなくフルスタック要員によるチーム構成の ために、組織内での責任分担は曖昧である」と述べている。

(2)プロジェクトコミット時間の長期化 :

Jared は「開発から施工管理まですべてを同一主体が担当するた め、個人がプロジェクトあたりの取組時間が長くなる(およそ 1-2 件 /年)」と述べている。

（3)拠点地域公益性重視型のコミュニティ投資スタンス：

Jared は「寄付ファンド設立などの取り組みを通してコミュニテ
イへ還元するなど、拠点である Brooklyn の Dumbo 地区のオーナ 一全員とのコネクションを大切にしている」と述べている。

\section{3-5. ALD の優位性と課題}

事例調查を踏まえて、ALDには以下のような優位点と課題がある と考えられる。

(優位点 1) Sweat Equity の活用 :

住宅不動産開発において金銭の代わりに設計業務などの技術能力 を提供(出資)する Sweat Equityにより、エクイティによる資金調達、 およびそれを元手にした融資獲得に充てられる。

（優位点 2）創造的なアクイジションプロセス：

従来形状の特殊な敷地選択はディベロッパーにとって設計フィー 上昇のリスクとなるが、ALD は効果的に空間設計に接続させること が可能。

（優位点 3 ）機能面でのデザインコントロールの拡張 :

全てのステークホルダーと直接関与することで、対象敷地周辺の コミュニティに必要な価值を理解し、ライフスタイルモデルをファ イナンスサイドに提案するなど、建築の機能面に関わる意思決定に 対するデザインサイドの関与割合が上昇する。

一方、ALD には次のような課題があると考えられる

(課題 1) ALD の事業主体の低クレディビリティに起因するリスク忌 避傾向が、デザイン選択に影響しや寸い。

(課題 2) 調查対象の Alloy Development に見られるインテグラル型 組織の内部構造を持続更新することの難易度が高い。

(課題 3)実例調查ではALDB で対抗しているものの、現状では施工 業者主導の DB 事業者の方に競合優位性があると思われる。

（課題 4）サブコンの倒産によるリスクを含め、プロジェクトが長期 にわたることに付帯するセトルメントリスクを引き受けなければな らない。

\section{3-6. 調査分析小結 : 資金調達の課題と開発に求められる公益性}

ALD においてアーキテクトが金融機関から長期的信用力を獲得 しょうとすると、元手となる資金力がない場合、補助金などを活用 しながらも投機的な開発による収益率重視の開発傾向をとる可能性 がある。一方で、このような開発傾向が原因の一端となる、ジェン トリフィケーション問題のような都市課題などに対しては、事業敷 地周囲のコミュニティへとの関係性を大切にし、地域経済を循環さ せるスキームを組み込むなど、周辺地域に対する公益性を最大化す る資金調達プロセスの設計能力も重要になると考えられる。

\section{4. 設計と資金調達}

\section{4-1. オルタナティブ · ファイナンス}

不特定多数からプロジェクトベースで資金調達を行う手段にパブ リックファイナンスなどがある。その中でも特に 2012 年の JOBS $\mathrm{ACT}$ 法改正注 14) 後、インターネット上のオンライン・プラットフ オームを通じて資金提供者と資金需要者を直接マッチングさせる形 で、伝統的な金融システムを補完する複線的な金融システムを構築 するオルタナティブ・ファイナンス(以下 $\mathrm{AF}$ )の市場が急速に拡大し ている(Figure.7)。このような金融包摂的な資本主義の構造変化傾 向には、前節で考察した ALD など建築設計開発における間接金融 主体の資金調達上の課題解決への実効性が期待できる。 

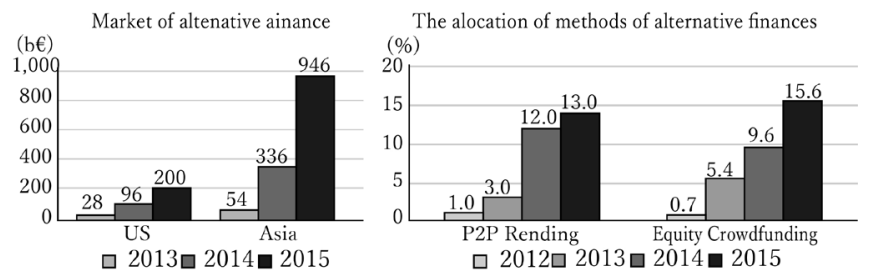

Fig.7 The transition of alternative finance market ${ }^{\text {注 }}$ 15)

\section{4-2. エクイティ型クラウドファンディング}

鬼頭注 16$)$ は $\mathrm{AF}$ の一種であるクラウドファンディング $(\mathrm{CF})$ は対価 の性質によって Table.3 のように分類が可能であるとしている。寄 付・購入型 $\mathrm{CF}$ は調達金額に限界があり、投資型 $\mathrm{CF}$ は融資型 $\mathrm{CF}$ と異なりプロジェクトベースにキャピタルリスクを投資家サイドに 分配する構造上、プロジェクト情報の透明性がより重要視されてい る点に特徴がある。

Table 3 Classification of crowdfunding target

\begin{tabular}{|l|l|l|}
\hline CF-Type & Value & Regulation(US/JP) \\
\hline Donation-Type & Non-Proprietary Value & None \\
\hline Rewards)-Type & Proprietary Value except Financial Products & $\begin{array}{l}\text { Apecified Commercial Act } \\
\text { 特定商取引法 }\end{array}$ \\
\hline Debt-Type & Liability Financial Instruments & $\begin{array}{l}\text { Securities Act of 1993 } \\
\text { 金融商品取引法 / 貸金業法 }\end{array}$ \\
\hline Equity-Type & Capitality Financial Instruments & $\begin{array}{l}\text { JOBS ACT(Reg CFなど) } \\
\text { 金融商品取引法 / 不動産共同特定事業法 }\end{array}$ \\
\hline
\end{tabular}

\section{4-3. AF に関する事例分析}

調查分析対象とした Guerrilla Development(以下 GD) は Portland 市において CF を利用した建築プロジェクトを手掛けてき た ALD の代表例である。

Figure. 8 注 17) は、調達資金の一部を、投資型 $\mathrm{CF}$ を通して公募 することで開発した社会住宅プロジェクトの一例「Jolene’s First Cousin」のキャッシュフローを説明した図である。市の補助金で 支払える家賃設定と、地元 NPO 団体と提携してホームレスの雇用 を生み出すビジネスモデルが設計されている。また、小規模商業テ ナントを混在させることで、同じ所得層が偏ることによるコミュニ ティの価值観の偏在化を抑止する設計提案も行っている。資金調達 の補助ツールとしてのみではなく、社会課題解決型のコンセプトに 包摂される公益性とリスクを、建築空間というアウトプットを媒体 としてパブリックに共有するための手段として、CF を活用してい ることがわかる。居住部分と共同ダイニング部分の配置はポートラ ンド市のゾーニング法 Chapter33.239 の Group Living に準拠した 構成をとり、プランニングの一つの特徴となっている。

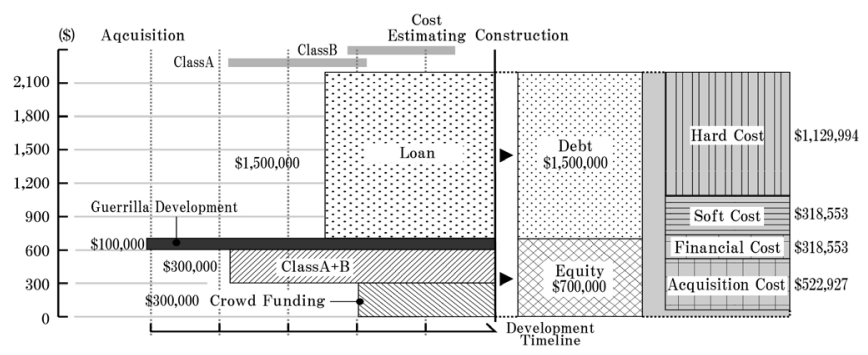

Fig. 8 注 1 7) Funding process of Jolene's First Cousin

4-4. 小結：建築デザインとファンディングデザイン

投資型 $\mathrm{CF}$ を活用した不動産開発は歴史が浅く事例は少ないもの の、地域公益性とデザイン主導の視点を統括的に内包する点で建築
家の現代的なデザイン手法の一つと言える。一方で、現状ではコン セプトデザインの側面が強く GD の場合、設計施工は外注すること もある。建築としてのデザイン要素とファンディングデザイン要素 の接続性の観点からは、将来的には ALDB・AIOP との接続や事業 スケール桩大の可能性も考慮する余地はあると考えられる。

\section{5. 建築家と分散型社会}

\section{5-1. 価值交換の類型}

パブリック領域における資金調達の要素間における価值交換のネ ットワーク構造は、鬼頭武嗣が $\mathrm{CF}$ 事業サービスの取引参加者の関 係性によって Table.4のような類型に分類している。

非中央集権分散型の $\mathrm{P} 2 \mathrm{P}$ モデルはパブリックチェーンと呼ばれ、 既存制約を排した ICO 注18) などの形で注目を浴びた。現在はセキ ユリティなどの課題対応としてレギュラトリーサンドボックス制度 が世界中で整備されるなど、分散型社会構築に向けた社会変容が起 きている初期段階にあるとも考えられる

Table 4 Classification of organization structure 注 19 )

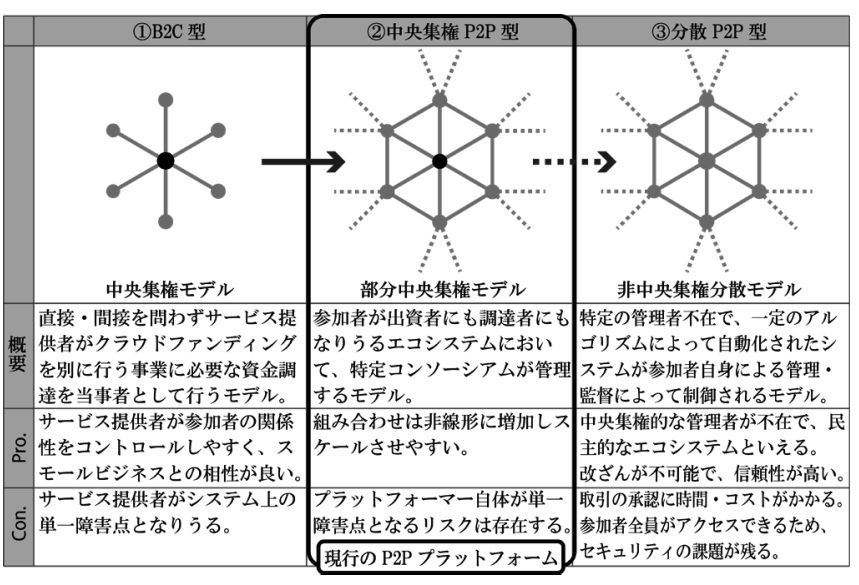

\section{5-2. P2P 直接金融プラットフォームの日米における実践}

鬼頭は、日本の資本市場における（価值交換の）需給マッチング の課題解決のための一手段として、Figure. 9 に示すような考え方に 基づき、投資銀行機能のプラットフォーム事業(Crowd Realty)を創 業している。オルタナィブな資金調達手法の提案と実践を事業者と して行いつつ、新市場における国境を越えた規制構築に寄与寸るた めの国際的活動も積極的に展開している。

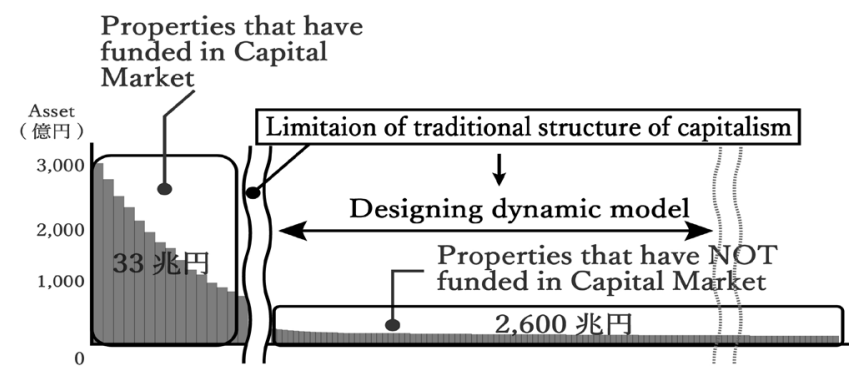

Fig. 9 Concept of Crowd Realty 注 19 )

米国では「Small Change(SC)」注20)などの P2P プラットフォー ム事業は既に複数見られる。例えば、Affordable Housing など課題 認識の比較的明瞭なコンセプトのプロジェクトーの適用事例や、民 
泊と AIR(Artist in Residence) の混成開発などを特定の地域内で組 み合わせた、ボトムアップ型の分散型都市開発手法を提唱する OJT (Office of Jonathan Tate ${ }^{\text {注 } 21)}$ ) と SC の協業などが見受けられた。

また、日本の「Crowd Realty」の事例では、築年数がわからず銀 行から融資が下りない京町屋の宿泊施設への転用開発プロジェクト や、シェアハウスと保育園との混成開発プロジェクトへの資金調達 などがあり、社会課題に対する当事者意識などとの関連性があると 推測できる。公益性とデザイン性の観点からのプロジェクト開発を 促進させるためには、地域ごとに最適化された循環経済のエコシス テムが必要であると考えられる。今後小口化された資産ポートフォ リオが増えるにつれて、インパクト投資などによる資金を地域内で 循環させる参加型の経済圈と建築生産プロセスを適切に接続させる 主体の役割の重要性が増すと考えられる。

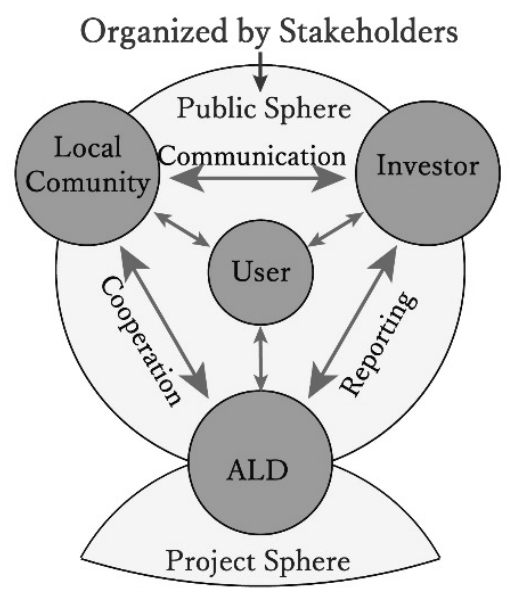

Fig. 10 Ecosystem in decentralized society

\section{5-3. 事例分析小結：建築家と分散型社会のエコシステム}

事例分析を通じて、パブリック領域において中央集権が存在しな い(あるいは部分分散して存在する)、分散型社会のエコシステム構 造が仮説的に浮かび上がってきた。それはFigure. 10 に示すように、 一定のアルゴリズムに基づくパブリックチェーンで構成されるエコ システム注 23$)$ に基づき、各コミュニティエリアで最適化された価 值交換プロセスを通して建築コンセプトが生み出されていく構造で
ある。このようなコンセプトをシームレスに具現化した建築空間を 適切に社会実装していくためには、統括的な視点に基づくマネジメ ントが必要となる。図 1 に示したデリバリーモデルのパブリック領 域 (Public Sphere)において元来存在しなかった、エコシステム構築 のためのプロトコル設計を担える職能が求められており、建築空間 の生産行為にまつわる重要な新職能と捉えられる。

\section{6. 結}

本論文では、米国における建築家の社会的意義の変容をテーマに 当事者インタビューを行い、総合的に考察した。本論文で報告した 事例分析に基づき、デリバリーモデルの変容を類型化したものを Figure.11 に示す。パブリック領域における建築家の職能領域の変 容と、プロジェクト領域におけるステークホルダー関係の変容は現 状独立して起きつつあるが、建築生産行為を媒体として部分的に重 複しうるという可能性があると思われる。

現状米国で起きている構造変化は民間市場で起きているものが中 心である。本論文で考察したような複合領域をまたぐ建築家として の職能を、公共事業市場に見られるような大規模複合型プロジェク トなどにも展開していくためには、既存の体制に対する新たなデリ バリーモデルの信頼性を高めることが不可欠である。そのためには、 デリバリーモデルをデザインする主体としての新職能が求められて おり、実績の蓄積を通じてその社会的意義が今後高まっていくと考 える。

なお本論文では、米国における建築契約形態や投資制度にまつわ る法規制の変容と建築家活動の応答の相互関係を扱っているため、 日本における実例調查や体制との関係性については議論の余地が残 る。今後の研究課題としては、グローバルの動向を注視しつつも日 本の社会制度の変容との対応関係を実証的に考えていく必要がある。

\section{謝辞}

調査にご協力いただき、論文に資料掲載を許可頂いた Gluck+, Leroy Street Studio, Alloy Development, Crowd Realtyに記して謝意を 表します。

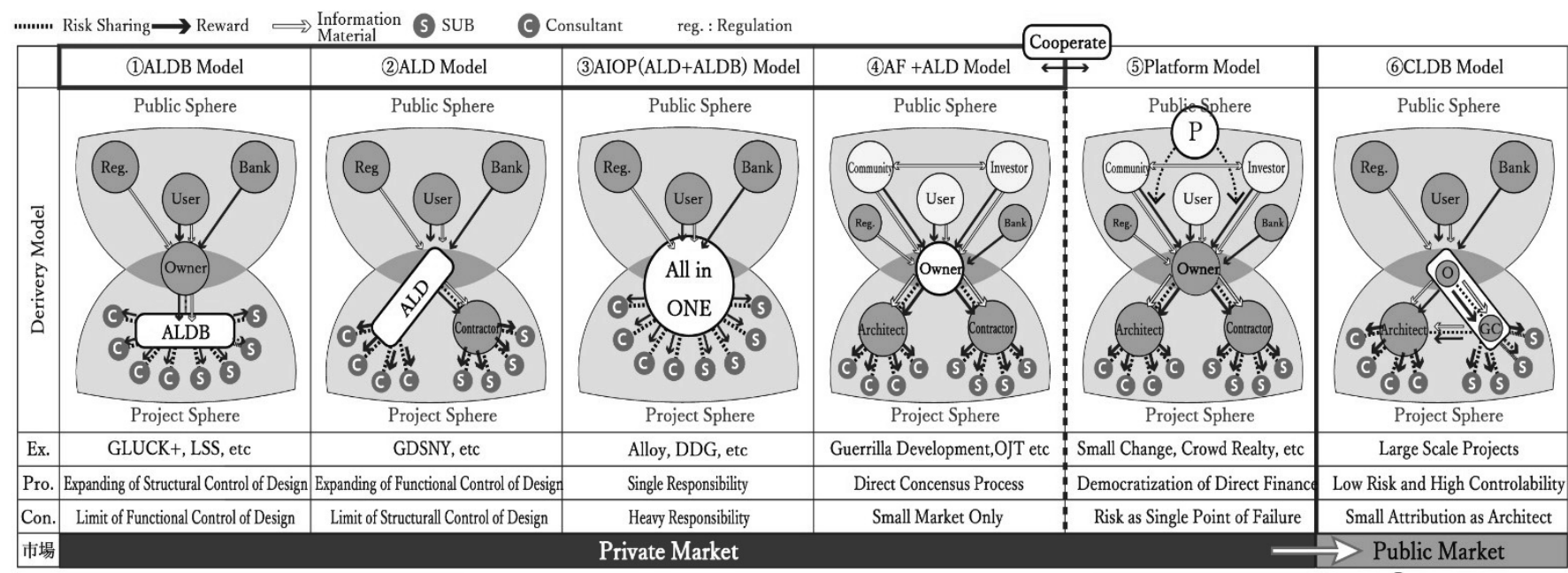

Fig.11 Typology of transition of delivery models 
参考文献

1) Phillip G. Bernstein; Architecture Design Data, Practice Competency in the Era of Computation, 2018.9.24

2) James Petty; Architect \& Developer, A Guide to Self-Initiating Projects, 2018. 1.23

3) Peter Hendee Brown; How Real Estate Developers Think : Design, Profits, and Community, 2015.5.5

4) Design-Build Institute of America, 2018, Revisiting Project Delivery Performance 1998-2018.

5) Mortimer, I.; Design Council, Building, Building Design and build Supplement., 1993.7.17.

6) Quatman, G. W., Dhar, R.; The Architect's Guide to Design-Builde Services, John Wiley and Sons, New Jersey, 2003,

7) Gary W. Eldred; IInvesting in Real Estate, 2012.4.3

8) Saskia Sassen; Expulsions : Brutality and Complexity in the Grobal Economy, 2019.4

9) Cambridge Center for Altenative Finance, 2016, Sustaining Momentum : The 2nd European Altenative Finance Industory Report.

10) Guerilla Development, http://guerrilladev.co/, December, 2019,10.28

11) Urban Land Institute, 2019, ULI Case Studies, Deal Profile, Jolene's First Cousin

12) SmallChange : https://www.smallchange.com/, December, 2019.10.31

13) Alexander R. Galloway; Protocol : How Control Exists after Decentralization, 2006.2

14) Syuzo, F.; Kenchikuseisan handbook, Handbook for Architecture Production, Asakura, 2007.7 古坂秀三他 建築生産ハンドブック，朝倉書店, 2007.7

15) Takahiro. F.:Kenchiku : Architecture as "Architecture" Yuhikaku, 2015.7 (in Japanese) 藤本隆宏他, 建築ものづくり論, 有斐閣, 2015.7

16) Ando, M.: The strength and weakness of Japanese architecture industry " How do the market, industry, and profession change?; The challenge and future of architecture industry in the era pf reform”, 2007 (in Japanese)

安藤正雄：本の建築産業の強みと弱夕「変革期における建築産業の課題 と将来像, その市場・産業・職能はどのように変わるのか」日本建築学 会, 102-107, 2007

17) Masanori, Y.: Architect and Profession, Seibunsya, 1980.10 (in Japanese)

山本正紀：建築家と職能, 建築家のプロフェッションとは何か, 清文社, 1980.10

18) Masatoyo,O.: The task distribution among architects: Matrix of Responsibilities in US projects, 2017 (in Japanese) 小笠原正豊：アーキテクト間の分業に関寸る基本的考察 米国建築プ ロジェクトにおける Matrix of Responsibilities を研究対象として, 2017

19) Takeshi, K.: Practical practices for the challenge of capital market with the platform of equity crowdfunding, 2019. (in Japanese) 鬼頭武嗣：クラウドファンディングプラットフォームを用いた資本市 場における課題解決の実践的取り組み, 2019

20) Crowd Realty: https://www.crowd-realty.com/, December, 2019.09.14

注

注1）具体的には ESG 投資市場の拡大、資本市場における不動産投資市場の アロケーション上昇傾向、そして JOBS ACT 法改正(2012 年米国)や不 動産特定事業法改正(2019 年日本)などに見られる規制詨応などを指し ている。

注2）具体的には情報技術の発達などによる IPD (Integrated Project Delivery）への移行傾向、Design Build 型プロジェクトの占有率上昇、 建築マネジメント研究の発展を指している。

注3）デリバリーモデルは参考文献 1 ）で使用されていた、モノ、資金、情報 の流れと関係性の図式を指す。日本においては主に IT 領域における $\operatorname{SCM}($ Supply Chain Management)で用いられることが一般的である。

注4）参考文献 14 )

注5）参考文献 1 )
注6）参考文献 17)

注7） Peer to Peer の略称。ビジネスモデル類型の一種で、等価な関係者間で 利害関係があるモデル。通常仲介するプラットフォームが存在する。

注8）参考文献 4)

注9）参考文献 16 )

注10)参考文献 5 )

注11)参考文献 6 )

注12)Critical Path Method 方式の略称。所要時間と費用の関係から最適工期 を割り出すもの。

注13)参考文献 2 )

注14)JOBS ACT は、実務家のワーキンググループである IPO タスクフォー スが米国財務省に提出した法案で、新興企業 (emerging growth companies）の市場内外での資金調達力を高め、公開企業となる夕イミ ングを自ら決定することを認める内容となっている。その中で最も特徴 的な改正が「Crowdfunding Exemption」条項であり、証券法 4 条に新 たな除外規定を設け、非公開企業が不特定多数の投資家に対し、登録な しに少額の募集を行うことを可能にするものである。

注15)参考文献 9 )

注16)参考文献 19 )

注17)参考文献 1 1）の公表している資料を基に筆者作成。 (https://casestudies.uli.org/deal-profile-jolenes-first-cousin/)

注18)Initial Coin Offering の略称。資金調達をしたい個人や企業、プロジェ クトなどがトークンやコインと呼ばれる独自の仮想通貨を発行し、それ を広く投資家に販売することで資金を集めることを指す。

注19)参考文献 19）と鬼頭氏のインタビューにおける証言や資料を基に筆者 作成。掲載許可済夕。

注20)Small Change(https://www.smallchange.co/)

注21) OJT Pffice of Jonathan Tate ; https://www.officejt.com/

注 22$)$ 数值は国土交通省第 11 回不動産投資市場政策懇談会配布資料(2019年 8 月 2 日)より。コンセプト図は参考文献 21 ）をもとに筆者加筆。

注23)エコシステムとはビジネス生態系を意味し、複数の企業や事業が互いに 連携や依存しながら、市場全体として共存共栄かつ成長していく仕組み のことを指す。本論文ではパブリック領域におけるステークホルダーの 関係性の仕組みのことを言う。 


\title{
A STUDY ON THE NEW PROFESSION OF ARCHITECT THROUGH THE CURRENT SOCIAL TRANSFORMATION
}

Based on the examples in the U.S.

\author{
Keisuke OKAMOTO ${ }^{* 1}$ and Tomonari YASHIRO*2 \\ ${ }^{* 1}$ Master Course, Dept. of Architecture, Faculty of Eng., The University of Tokyo \\ ${ }^{*}$ Prof., Institute of Industrial Science, The University of Tokyo, Dr.Eng.
}

This study typifies the transformation of the profession of architect through interviews with professional cross-border architects, who have recently attracted attention in the United States. The social background referred to in this study refers to changes in laws and regulations due to inclusive changes in the financial industry, and the increasing importance of management theory with the spread of design build contracts. Further, since the profession of architect is not codified in Japan, this paper refers to all those who contribute in the form of brain labor to the social implementation process of space.

Chapter 2 first summarizes the design-build research conducted in the United States. The architects interviewed two companies that are involved in the Architect-Led Design-Build business. In addition to confirming the merits of both the clients and business operators, the institutional barriers and operational issues are also clarified.

In Chapter 3, the business model that helps develops both the design and development industries is defined as an Architect-Led-Developer ; further, and James Petty's discussions on the Architect-Led-Developer business are presented. In addition, we interviewed the companies and obtained data. Financing issues and development policies, amongst other issues that consider public interest were discussed.

Chapter 4 summarizes the changes in financing methods and analyzes the case studies of companies that are conducting investment-type crowdfunding businesses in Portland. We analyzed four case studies, including a developmental and operational project ensure affordable housing and commercial stores in cooperation with Non-Profit-Organization. Through examples, we confirmed that architects contribute to the construction of a regional investment ecosystem.

In Chapter 5, the business models of platform operators are organized into three types: centralized B2C type, centralized P2P type, and decentralized P2P type. By analyzing the limitations of the current laws and regulations and the government's response, we analyzed the global practices for a decentralized society.

In conclusion, we categorized the analyzed cases and proposed the social significance of architects as subjects who comprehensively model designs.

$(2020$ 年 4 月 5 日原稿受理, 2020 年 12 月 2 日採用決定 $)$ 